\title{
乾海苔の $5^{\prime}$ イノシン酸とその酵素的生成
}

\author{
荒木 繁*・桜井武穈* $\cdot$ 泉野友香 ${ }^{*} \cdot$ 高橋幸資 ${ }^{* *}$
}

\section{5'-Inosinic Acid Content and its Enzymatic Increase in Dried Nori, Porphyra yezoensis, a Red Alga}

\author{
Shigeru ARaki*, Takemaro SaKURAI*, Yuka IzUmino* \\ and Koji TAKAHASHI* \\ * Yamamoto Nori Research Laboratory, 5-4-6, Oomori-Higashi, Oota-ku, Tokyo 143 \\ ** Tokyo University of Agriculture and Technology. Faculty of \\ Agriculture, 3-5-8, Saiwaicho, Fuchu-shi, Tokyo 183
}

\begin{abstract}
The contents of 5 -inosinic acid (5'IMP) in dried and toasted nori, sheet-like products of Porphyra yezoensis (a red alga), were measured with HPLC from the standpoint of an enzymatic increase in them, and the following facts were observed. 1) 5'IMP was not determined by HPLC in the case of directly extracting the sample with $80 \%$ ethanol, while $5^{\prime}$-adenylic acid (5'AMP) and $5^{\prime}$-guanylic acid were. However, a considerable amount of 5 'IMP could be determined when soaking the sample in a small volume of water for a short time prior to the ethanol-extraction, and it was, moreover demonstrated that an increase in the 5'IMP content was followed by a decrease in the 5'AMP content. 2) The maximum production of 5'IMP was attained by soaking for 180 or $120 \mathrm{sec}$ for dried or toasted nori, respectively. 3) In both samples of nori, the $5^{\prime} \mathrm{IMP}$ content reached the maximum at $30-40^{\circ} \mathrm{C}$ in the soaking temperature, but could not be determined above $75^{\circ} \mathrm{C}$. In commercial toasted nori, considerable amounts (201-304 mg/100 g dry matter) of 5'IMP could be determined with pre-soaking at $30^{\circ} \mathrm{C}$ for $120 \mathrm{sec}$. 4) The extract of dried nori with $50 \mathrm{mM}$ tris-acetate buffer at $\mathrm{pH} 6.5$ containing 3 $\mathrm{mM} 2$-mercaptoethanol and $10 \mathrm{mM} \mathrm{CaCl}_{2}$ showed high activities of 5'AMP deaminase. These results strongly suggest that 5'AMP deaminase in dried nori takes part in the increase of 5'IMP content.
\end{abstract}

(Received Jan. 24, 1996)

乾海苔は、その独特の旨味と高い栄養価により，古来 から日本人に親しまれてきた, いわゆる伝統食品のひと つである. 乾海苔には, アミノ酸, とくにグルタミン酸 やアラニンなどの呈味性をむったアミノ酸が極めて多く 含まれている.これに加えて，5'イノシン酸 (5'IMP) の 存在が認められておりここらの物質が乾海苔の旨味を ひきおこす中心的な成分になっているあのと考えられ る. 5'IMPは，獣肉や魚肉には普通に見出だされるが, 植物組織中においてはきわめて希で，乾海苔における 5 ” IMP の存在は，特異的であり，興味深い．

乾海苔の 5'IMP の含量については, いままでに2, 3
の報告がみられるが, 研究者の間で必ずしも一致した分 析值が得られていない，野田ら”は，わが国のいろいろ な産地で生産された乾海苔について 5'IMP の含量を調 ベた結果, 乾海苔 $100 \mathrm{~g}$ 当たり 2.2-8.5 $\mathrm{mg}$ であったと報 告している.これに対して，中村ら²) は，千葉県産の乾 海苔の 2 つの試料のうち, 1 つの試料で $40 \mathrm{mg} / 100 \mathrm{~g} \cdot$ 乾重の 5'IMP が認められたが, 他の試料ではまったく検 出できなかったとしている。このような差異の是非や理 由は不明のまま残されている。すでに述べたように5' IMP は, 乾海苔の重要な呈味成分であり, その含量を明 らかにすることは意味潹いことと考えられる.

* 山本海苔研究所（干143 東京都大田区大森東 5-4-6)

** 東京農工大学・農学部（干183 東京都府中市幸町 3-5-8） 
著者らは，畭海苔の品質と呈味成分の関係を調べる 連の過程において，乾海苔に含まれる $5^{\prime}$ アデニル酸 (5' AMP）が酥素的に5'IMP に変化する可能性を見出だし， それゅえに，いままでに報告された乾海苔中の 5'IMP の 測定值よりるはるかに高い值がえられたことなどいくつ かの知見を得た．この報告は，それらの知見を述へ，乾 海苔における 5'IMP の生成とその意義について 2，3の 考察を試みたものである.

\section{実験材料と方法}

\section{1. 試 料}

主として九州の有明海地区で養殖されたスサビノリ (Porphyra yezoensis) の葉体を摘採後，直ちに水洗い し，細切して抄き上げ，機械乾燥によって製造した乾海 荅を試料に用いた，試料は，入手後ただちに二次乾燥 （約 $50^{\circ} \mathrm{C}, 2-3$ 時間）により水分含量を $3 \%$ 前後に低下さ せた後，乾燥剤とともに密封して，分析に供するまで $4^{\circ} \mathrm{C}$ で眝蔵した，焼海苔は，約 $200^{\circ} \mathrm{C} て ゙ 5$ 秒間加熱して 製造したものを用いた。

\section{5’イノシン酸の抽出}

試料 $(0.5 \mathrm{~g})$ に $50 \mathrm{ml}$ の $80 \%$ エチルアルコールを加 え，冷却管を付して，沸騰水浴中で 15 分間抽出した。同 梯な操作を 3 回絽り返し，すべての抽出液を合わせて減 圧下で浱䑿した，浱䑿液を分液漏斗に移し，エチルェー テルを加えて振とうしたのち，静置して，エーテル層と 水層の二層に分け，水層を回収した，水層はさらに 2 回 エチルェーテルで脱脂した後, 減圧下で少量に潡縮し た。この液を活性炭カラム $(5 \mathrm{~cm} \times 1 \mathrm{~cm})$ に目荷し，含 まれるヌクレオチド類を吸着させた後，1.4\%アンモ二 ア50\%エ夕ノール溶液で溶出した，溶出液は定容した のち，その一部をとり，乾固するまで咸圧下で溶媒を完 全に除去した。乾固物は， $1 \mathrm{~m} l$ の $0.05 \mathrm{M}$ リン酸䌅衝液 （pH 3.35）に溶功しこれをHPLC 分析の試料液とし た.

\section{5’ ヌクレオチドの分析と同定}

抽出液に含まれる5'ヌクレオチドは，島津製作所製 LC-10 A 型 HPLC で分離，定量した．使用したカラム は， Shim-pack WAX-1（島津製）で，カラム温度は

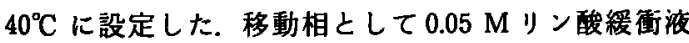
（pH 3.35）を流速 $1.0 \mathrm{~m} l /$ 分でカラムに流した．分離した 5’ ヌクレオチドは, $260 \mathrm{~nm}$ の吸光度で検出した. 5’ ヌク レオチドの同定わよび定量は，一定濃度の 5 ヌクレオチ ド純品（シクマ社）を標準液とし，それぞれの保持時間 とピーク面積の比較によって行った。

\section{結果と考察}

1. 5’ ヌクレオチドの HPLC クロマトグラム

Fig. 1 は乾海苔の抽出液と 5 ヌクレオチド標準液の HPLC クロマトグラムを示したものである．Fig. 1 (A) は，試料を直ちに $80 \%$ 熱エタノールで抽出したときの 抽出液のクロマトグラムを, Fig. 1 (B) は少量の $30^{\circ} \mathrm{C}$ の温水に 3 分間浸漬し，その後，終濃度 $80 \%$ になるよう にエタノールを加えて（A）之同様にして抽出したとき の抽出液のクロマトグラムを示したものである．また， Fig. 1(C) は，5' ヌクレオチド標準物質のクロマトグラ ムである.

Fig. 1 (A)，(B) にみられるピーク1，2および3の保 持時間は，それぞれ標準物質として用いた 5 アデニル酸 (5'AMP)，5’1ノシン酸 (5'IMP) および，5’グアニル酸 (5'GMP）のそれと一致した。また，試料からの抽出液 (A)および(B) と標準物質 (C) との co-chromatography を行ったときそれぞれのピークの保持時間は完全に一 致した。このことから，Fig.1(A)，(B)におけるピーク 1，ピーク 2 およびピーク 3 はそれぞれ 5'AMP，5'IMP および5'GMP と同定した。しかし，試料の抽出液にお ける 5’シチジル酸 (5’CMP) の存在は明らかではなかっ た.

Fig. 1 にみられるように, (B) では5'AMP と 5'IMP, 5'GMPがそれぞれ検出されたが，(A) では5'IMP は検 出されなかった．加えて，(B)においては5'IMPが検出 されたことおよび5'AMPが（A）において検出された 5 AMP 量に比へて著しく滅少していることが注目され た。このような事実は，5'IMP が乾海苔中にはじめから 生成，存在するすのではなく,80\%エタノール抽出に先 立って温水に浸漬された際に，5'AMP の一部が 5'IMP に変化した可能性を示唆している，なお（A）において 5'IMPが検出されなかったことは，5'GMPが（B）にお けるそれと同等なレベルで検出されていることから，抽 出が不十分であったことに原因するものとは考元られな い.

\section{2. 漫清時間と漫清時の水温の影暂}

Fig. 1 の実験結果から，乾海苔における 5'IMP の生成 には，乾海苔を水に浸漬することが必要な条件であるこ とが示唆された，そこで，5'IMP の生成と浸清時間おょ び浸漬時の水温との関係を調べた. Fig. 2 は，焙焼前 (乾海苔) と焙焼後（焼海苔）の試料を 30 秒-300 秒の範 囲で $30^{\circ} \mathrm{C}$ の温水の浸清し，その後， $80 \%$ のエタノール で抽出して得られた抽出液中の 5’ ヌクレオチドの変化 

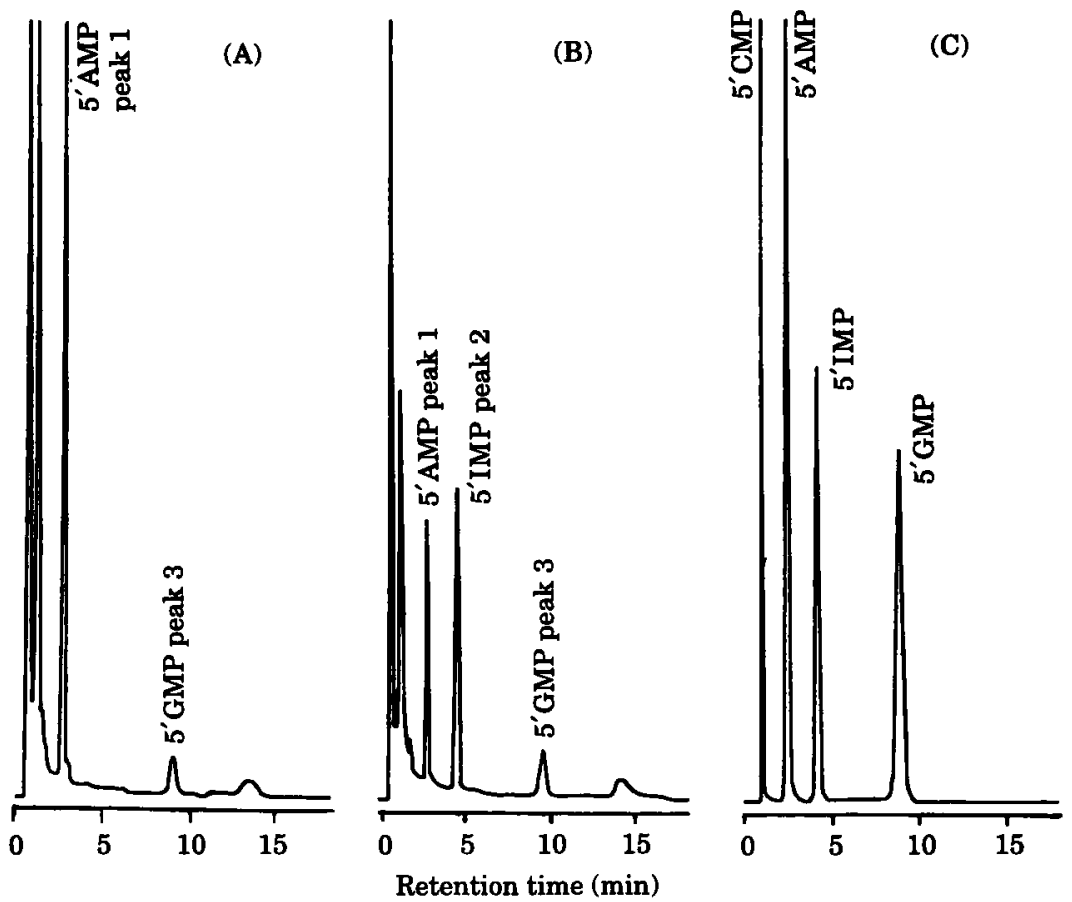

Fig. 1 HPLC-chromatograms of 5'nucleotides extracted from dried nori

(A), the extract with $80 \%$ ethanol ; (B), the extract with $80 \%$ ethanol after soaking in water at $30^{\circ} \mathrm{C}$ for 3 min ; (C), authentic 5'nucleotides.

The sample $(0.5 \mathrm{~g})$ was extracted with $80 \%$ ethanol at $100^{\circ} \mathrm{C}$ for $15 \mathrm{~min}$, evaporated and washed with ether. The crude 5 'nucleotides were purified on an active charcoal column with $1.4 \%$ aqueous ammonium-50\% ethanol as a solvent.

HPLC conditions : apparatus, Shimadzu LC-10 A ; column, Shim-pack WAX-1 (Shimadzu); mobile phase, $0.05 \mathrm{M}$ phosphate buffer $\mathrm{pH} 3.35$; flow rate, $1.0 \mathrm{ml} / \mathrm{min}$; detection, absorbance at $260 \mathrm{~nm}$.

を示したあのである.この図で見られるように，乾海荅

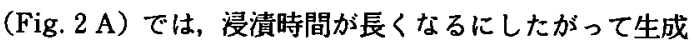
する 5'IMP は増加するが，180 秒以上の浸清時間では生 成量は飽和状態になった。これに対して，5’AMPは 5 ’ IMP の生成量の増加に反して隇少し, 5'IMP の生成が飽 和に達する 180 秒以降では，それ以上の減少は見られな かった，5'GMP は浸清時間に関係なく，ほとんど増隇は 見られなかった，焼海苔においても同粎な関係がみられ た (Fig. 2 B) が, 5'IMP の生成は焙焼前の乾海苔とは異 なり，はじめ急激に増加した後，楥やかに増加して 120 秒前後で飽和に達した。

Fig. 3 は, 乾海苔を試料として, 種々の温度の水に浸 清したときの各 5 ヌクレオチド含量の変化を定量した 結果である，10-40 $\mathrm{C}$ までは水温の上昇とともに5'IMP の生成量は增加した。しかし，40 $\mathrm{C}$ を越えると急激にそ
の生成量は減少し， $75^{\circ} \mathrm{C}$ では $5^{\prime} \mathrm{IMP}$ の生成は完全に抑 制された。この場合も5'AMP は5'IMP の変動とは逆の 変動を示した.これに対して,5'GMP は水温に関係なく ほとんど同じレべルを維持していた。

以上の結果は，乾海苔における 5'IMP の生成が，5’ AMP の非䣼素的な化学変化によるものではなく, 武料 を温水に浸清している間に，䤃素的に，すなわち 5'AMP デアミナーゼの作用によって生成したすのであることを 強く示唆している。海苔における5'AMP デアミナーゼ の存在は, いままてに, P. perforata ${ }^{3)}, P$. crispata $^{4)}, P$. tenera $^{2)}$ およびP. yezoensis ${ }^{53}$ の生藻体において報告さ れているが，乾海苔での報告はない.

\section{3. 乾海苔中の 5'AMP デアシーゼ}

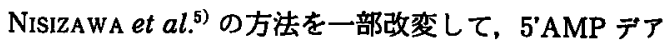
ミナーゼの抽出を試みた。すなわち，試料 $1 \mathrm{~g} に 3 \mathrm{mM}$ 

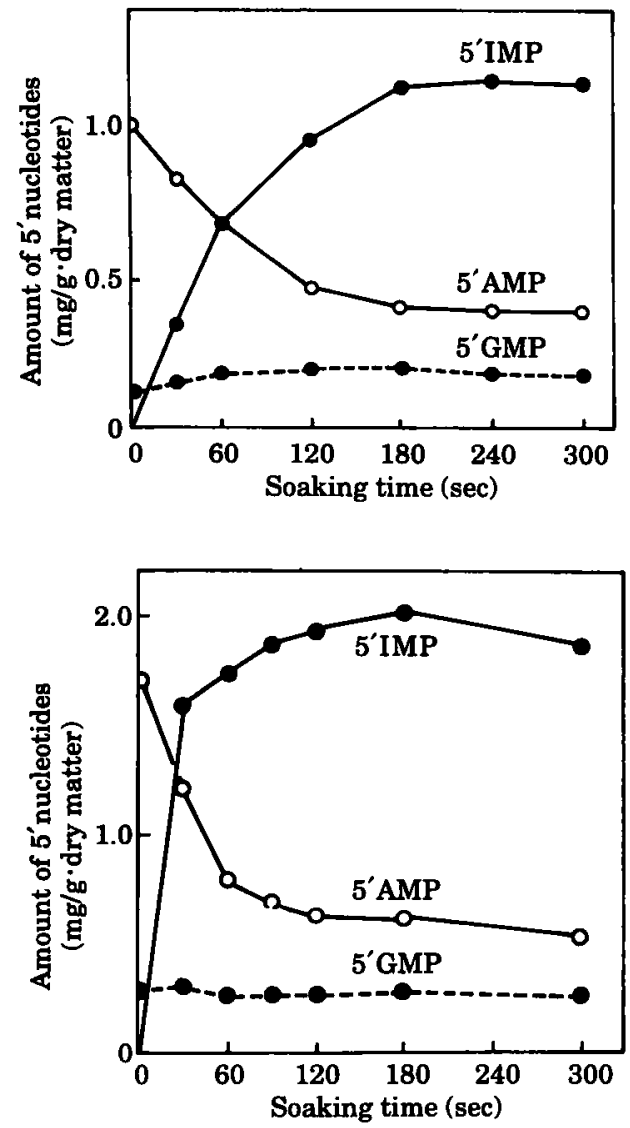

Fig. 2 Effect of soaking time on 5'nucleotide contents

(A, upper), dried nori ; (B, lower), toasted nori. The samples were soaked in water at $30^{\circ} \mathrm{C}$ prior to the ethanol extraction and analyzed by HPLC.

の2-メルカプトエタノールと $10 \mathrm{mM}$ の $\mathrm{CaCl}_{2}$ を含む $30 \mathrm{ml}$ の $50 \mathrm{mM}$ トリス一酢酸䌅衝液（pH 6.5）を加え， 少量の海砂とともに乳鉢中で磨砕・抽出した．抽出液は サラン布で滤過した後, $0^{\circ} \mathrm{C}$ で $10000 \mathrm{rpm} \times 30 \mathrm{~min}$ で 遠心分離した。 上清液から5'AMPおよび金属や塩類を 除去するため抽出に用いたと同じ組成のトリス一酢酸緩 街液に対して $5^{\circ} \mathrm{C}$ で $2 \mathrm{~h}$ 透析し，ここに得られた透析液 を活性確認のための醉素液として用いた。

$30^{\circ} \mathrm{C}$ に保持した醉素液 $1 \mathrm{~m} l$ 当たり $10 \mu \mathrm{g} の 5$ AMP を添加して反応を開始し， $5,10 ， 15$ 分後に反応液を分取 し，直ちに 3 倍容の冷エ夕ノールを加えて激しく振とう して反応を停止させ, $2000 \mathrm{rpm} \times 10$ 分で遠心分離した.

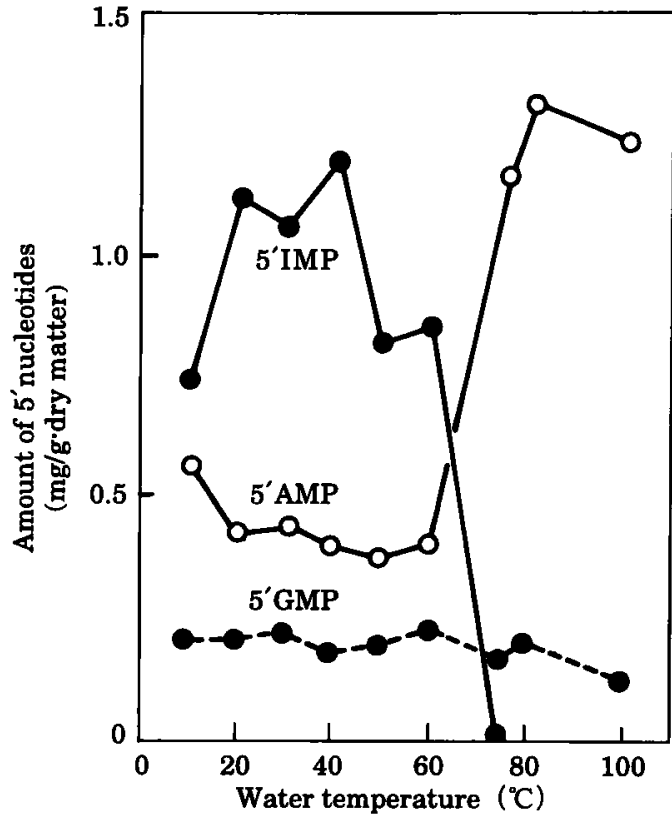

Fig. 3 Effect of soaking temperature on 5' nucleotide contents

The samples were soaked in water for $5 \mathrm{~min}$ prior to the ethanol extraction and analyzed by HPLC.

上清を減圧下で上清中の溶媒を完全に除去した後，少量 の水に溶解した. その後の HPLCのための試料液の調 製は，“実験材料と方法”に述べた手法にしたがった.

抽出液中の 5'IMP の生成に関与する 5'AMPデアミ ナーゼの活性は，抽出直後から次第に減少し，水冷下に おいてす $2 \mathrm{~h}$ 後には完全に失活したが, 抽出液に $10 \mathrm{mM}$ の $\mathrm{CaCl}_{2}$ を添加することにより, 冷蔵庫中に一夜放置し ても活性は，抽出時と同程度に維持されていた．このこ とは, カルシウムが活性の女定化に必須であることを示 している. NisizAWA et al.5) は, 生藻体から抽出した 5’AMP デアミナーゼ活性が, 添加したカルシウムの増 加により活性が著しく促進することを報じている．しか し, 乾海苔においてはカルシウムの添加が 5'IMP の生成 を促進するかどうかは明らかではなかった．以上のこと は，乾海苔中にも5'AMP デアミナーゼが存在すること を強く示唆している，そこで，本抽出液をここでは 5 AMP デアナーゼ粗抽出液と呼ぶことにした。

Table 1 は, 乾海苔の 5'AMP デアミナーゼ粗抽出液 に $10 \mu \mathrm{g} の$ 5'AMP を添加したときの 5'IMP の生成量の 
変化を示したものである. $30^{\circ} \mathrm{C} \cdot 5 \mathrm{~min}$ の反応で 5 IMP が反応液中に検出され，さらに反応時間を延長すること により，5'IMP の生成量は增加した。一方， $75^{\circ} \mathrm{C} \cdot 15$ 分 の反応では 5'IMP の生成は見られなかった。このような 結果は，原藻の摘採加乾燥過程を経て，乾海苔として 製品化された後にも，5'AMPデアミナーゼの活性が残 存していることを示している.

Table 1 The amount of 5'IMP formed in the crude enzyme solution incubated with 5' AMP for different times

\begin{tabular}{cc}
\hline \hline $\begin{array}{c}\text { Incubation } \\
\text { time }\end{array}$ & $\begin{array}{c}\text { 5'IMP formed } \\
(\mu \mathrm{g})\end{array}$ \\
\hline $30^{\circ} \mathrm{C} \quad 0 \mathrm{~min}$ & 0.1 \\
5 & 1.1 \\
10 & 2.0 \\
15 & 2.2 \\
$75^{\circ} \mathrm{C} 15 \mathrm{~min}$ & 0.0 \\
\hline
\end{tabular}

The crude enzyme solution of 5 ' AMP deaminase was prepared from dried nori by extracting with $50 \mathrm{mM}$ tris-acetate buffer $(\mathrm{pH}$ 6.5) containing $3 \mathrm{mM} \mathrm{2-mercaptoethanol} \mathrm{and} 10$ $\mathrm{mM} \mathrm{CaCl} 2$ and dialyzing for $2 \mathrm{hrs}$ against the extraction buffer. The crude enzyme solution $(1 \mathrm{ml})$ was incubated with $10 \mu \mathrm{g}$ of 5 'AMP at $30^{\circ} \mathrm{C}$ and $75^{\circ} \mathrm{C}$ for $0-15 \mathrm{~min}$. After adding three volume of ethanol, the supernatant was evaporated and dissolved into $1 \mathrm{~m} l$ of $50 \mathrm{mM}$ citrate buffer $(\mathrm{pH} 2.2)$ to analyze by HPLC.

HPLC conditions, see to Fig. 1.

\section{4. 各産地の焼海苔の 5'IMP 旦}

一般に，乾海苔は一度焼海苔に製して賞味しているの で，各産地の乾海苔を焙焼したのち，それぞれ 5’IMP 量 を比較した．烧海苔の 5'IMP 量は，試料を水に浸清する 際の条件によって異なるが，Fig. 2 および 3 の結果から $30^{\circ} \mathrm{C} \cdot 120$ 秒間の浸漬で生成量が最大になることから, この条件により比較を試みた。

Table 2 は，各産地の乾海苔を焼海苔とし，上述の条 件にしたがって温水に浸清して得られた抽出液の 5'IMP 量を調べた結果である。.5'IMP 量は試料間で異なるもの の非常に高含量を示し, $201-304 \mathrm{mg} / 100 \mathrm{~g}$ (乾量) の範 囲にあった。 また，それらの值と焼海苔の品質との間に は多少の関連性が認められた，すなわち，品質の良好な 海苔の方が，5'IMP 含量が高い傾向にあった。一方, 同 時に測定された 5'AMP と5'GMPは，それぞれ $100 \mathrm{~g}$ 乾 重当たり 44-118 mg と 40-67 mg で品質との関連性は 明らかではなかった。

乾海苔は，摘採した原藻をシート状に乾燥するための 一次乾燥とそれをさらに保存性を良くするために行う二 次乾燥という $2 つ の$ 乾燥過程を経て市場に供給される. 焼海苔ではこれに焙姪工程が加わる．このようないくつ 加の加熱工程が加えられたのちにおいても，乾海苔や焼 海苔に 5'AMP デアミナーゼが残存していることは注目 に值する.すなわち，この酵素が残存することにより， 水に短時間浸清しただけで 5 IMP が相当量生成し, 後述 のように海苔を食したときの呈味性に関与する.

乾海苔を抄製するには，原藻を真水で洗浄し，細断し てシート状に抄きあげ, それを $50^{\circ} \mathrm{C}$ 前後で 2-3 時間乾 燥する. したがって，この乾燥過程で，原藻が，十分な

Table 2 The amounts of 5'nucleotides in toasted nori produced at different cultivation fields

\begin{tabular}{|c|c|c|c|c|}
\hline Cultivation field & Grade & 5'AMP & 5'IMP & 5'GMP \\
\hline Minami-Kawazoe (Saga Pref.) & high & 62 & 286 & 62 \\
\hline Minami-Kawazoe (Saga Pref.) & middle & 44 & 230 & 50 \\
\hline Minami-Kawazoe (Saga Pref.) & low & 60 & 225 & 45 \\
\hline (Saga Pref.) & high & 81 & 304 & 55 \\
\hline (Saga Pref.) & low & 51 & 201 & 40 \\
\hline (Fukuoka Pref.) & high & 85 & 235 & 57 \\
\hline (Fukuoka Pref.) & middle & 118 & 237 & 66 \\
\hline Koromozaki & high & 72 & 260 & 67 \\
\hline
\end{tabular}

All figures were presented as $\mathrm{mg} / 100 \mathrm{~g}$ dry matter.

The toasted nori was prepared from dried nori by toasting at $200^{\circ} \mathrm{C}$ for $5 \mathrm{sec}$.

The preparation and analytical conditions of HPLC sample solution, see to Fig. 1. 
水分を含んだ状態で, $30-40^{\circ} \mathrm{C}$ の温度帯を経過し, 5 IMP を生成するのであろうと考えられる。しかし，本実験で は乾海荅には, 5'IMP が存在しないか, 存在してもこく 僅かであることが確認された。この原因については明ら かではないか，魚肉や獣肉のように死後の自己消化によ り 5'IMP が生成する゙)のとは異なり，海苔では比較的生 きた状態の組織構造を維持したまま，言い換えれば自己 消化をおこすことなく乾燥, 脱水されるため, 5’AMP デ アミナーゼの作用がないまま乾海苔に製せられるものと 考えられる. しかし，乾海苔を水に浸清すると，組織が 破壊されて 5'AMPデアミナーゼが㗢きやすくなるもの と推察される.焼海苔では婄焼することにより組織が破 壊されるので，水に浸漬することにより醉素がさらに作 用しやすくなり，かつ生成した 5'IMP も外部に溶出しゃ すくなるものと考えられる，燒海苔では，乾海苔よりあ 短時間 (30 秒間) の浸漬で, 5'IMP 生成の最高値に近い 量の 5'TMP が生成したという事実は，上述の推察を裏付 けるものといえよう。乾海苔は焼海苔として食されるの が普通で，それがロに含まれて食味を感じ㷛下されるま での時間は極く僅かで, 長くてあ 30 秒でそれ以下の短 い時間である. しかし，そのような短時間においても， 相当量の5'IMPが生成され, それが唾液中に溶出して, 海苔の呈味性に関与するものと推察される.

乾海苔の 5'IMP 量は, 水への浸漬時間と水温に左右さ れるが、そればかりでなく、残存する5 AMPデアミ ナーゼの活性と 5'AMP 量も重要な因子である。乾海苔 の製造過程で，これらの因子がどの程度残存するかを明 らかにすることは，今後のより良い製造工程を考えるう えで重要であるといえる.

\section{要約}

乾海苔の 5’イノシン酸 (5'IMP) の含量を調べるため, 試料を $80 \%$ エタノールで抽出した場合と, それに先
立って数分間温水に浸漬して水戻しを行ったのちエタ ノール抽出をした場合とを比較した。 その結果, 前者で

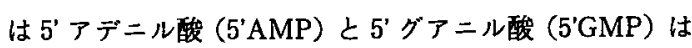
検出されたか，5IMPは認められなかった。これに対し て, 後者では 5'AMP と 5'GMP とともに5'IMP が検出 されたこのことから，5'IMP の生成には試料を水に浸 清することが必須であることが示唆された，そこで5” IMP の生成と試料の浸漬時間および水温との関係を調 べた結果，5’IMP の生成量は，乾海苔では 180 秒，焼海 苔では 120 秒の浸漬時間で飽和に達し， $30-40^{\circ} \mathrm{C}$ の水温 で最高値を示した。これらの実験において，5'IMP の生 成にともなって 5’AMPの低下がみられた。しかも， $75^{\circ} \mathrm{C}$ では 5'IMP の生成はみられなかった。

これらの事実は, 乾海苔に5'AMP デアミナーゼが存 在し，水に浸漬したとき，この酵素が 5'AMPに作用し て急激に 5'IMP が生成されることを示唆している。この ことは，さらに乾海苔の 5'IMPは，それをロに含んで咀 罚している間に生成することを示唆している.

\section{考文献}

1) Noda, H., Horiguchi, Y. and ARAKI, S. : Bull. Jap. Soc. Fish., 41, 1299 (1975).

2) Nakamura, S., Akagawa, H., Ikawa, T. and KaWANabe, H., : Bot. Mag. Tokyo, 81, 550 (1968).

3) Su, J.C. and HASSID, W.Z. : Biochem., 1, 474 (1962).

4) Su, J.C., LI, C.C. and Ting, C.C. : Biochem., 5, 536 (1966).

5) Nisizawa, K., OKada, Y., Kubo, K. and AnZai, H., : Jap. J. Phycol, 28, 205 (1980).

6）小原正美 : 食品の味 光琳全書 9 （光琳書院，東 京), p. 97 (1971).

（平成 8 年 1 月 24 日受理） 